\title{
Protein Analysis of Marjoram Plants Treated with Biocontrol Agents
}

Islam M. H. Rizk ${ }^{1 *}$, Mohamed M. M. Amaar ${ }^{2}$ and Ibrahim A. Ibrahim ${ }^{3}$

${ }^{1}$ Departmentof Environmental Biotechnology, Genetic Engineering and Biotechnology

Research Institute, University of Sadat City, Egypt.

2Department of Agricultural Botany, Faculty of Agriculture, Minufiya University, Egypt

${ }^{3}$ Department of Plant Biotechnology Genetic Engineering and Biotechnology Research Institute, University of Sadat City, Egypt.

${ }^{*}$ Corresponding Author; Email: islam rizk2@yahoo.com

\begin{abstract}
Origanum majorana $L$. commonly known as sweet marjoram has been used for variety of diseases in traditional medicine, including gastrointestinal, ocular, nasopharyngeal, respiratory, cardiac, rheumatologic, and neurological disorders. Protein gel electrophoresis is the commonly used technology to separate proteins according to their physical properties such as electrical charge and molecular weight.In present study, polyacrylamide gel electrophoresis (SDS-PAGE) was used for identification of marjoram plants treated with biocontrol agents collected from Egypt and studying the differentiations among them.SDS-PAGE was examined for plants treated with four biocontrol agents;Bacillus megaterium,Fusarium aquaeductuum,Trichoderma harzinum+Fusarium aquaeductuum and Bacillus megaterium+Trichoderma harzinum + Trichoderma hamatum+Fusarium aquaeductuum. Protein analysis revealed that, application of the biocontrol agents significantly increased protein bands than control or plants cultivated in the infested soil, best results were obtained when B. megaterium was applied.
\end{abstract}

Keywords: Keywords: Origanum majorana, traditional medicine, Fusarium aquaeductuum, polyacrylamide gel electrophoresis (SDS-PAGE), Majorana hortensis

\section{INTRODUCTION}

Origanum majorana $L$. from the family Lamiaceae (syn. Majorana hortensis Moench) is commonly known as sweet marjoram. This herb is native to Mediterranean region and cultivated in many countries of Asia, North Africa, and Europe, for example, Spain, Hungary, Portugal, Germany, Egypt, Poland, and France. Origanum majorana grows up to 30 to $60 \mathrm{~cm}$ (Novak et al., 2008; El-Ghorab et al., 2004). It is a perennial bushy plant. It has oblique rhizome, hairy shrub like stalks, opposite dark green oval leaves and white or red flowers in clustered bracts. The leaves are whole, larger ones being fragmented, oblate to broadly elliptical.1-3 This plant is widely usedas a garnish and is used for different medicinal purposes in traditional and folklore medicine of different countries(Ramadan et al., 2013; Abdel-Massih et al., 2010). Various compounds have been identified in sweet marjoram. Also, different pharmacological activities have been attributed to this plant (Abd and El-Metwally, 2010; Al-Howiriny et al., 2009; Amarowicz et al., 2009). The present review summarizes comprehensive information concerning traditional uses, phytochemistry, and pharmacological activities of sweet marjoram. For this purpose, 
databases, including PubMed, Google Scholar, and Scopus were searched for studies focusing on the ethnomedicinal use, phytochemical compounds and pharmacological activities of sweet marjoram. Data were collected from 1980 to 2015 (up to July). The search terms were "sweet marjoram" or "Origanum majorana" (Dragland et al., 2003)

Proteins are important constituents of foods for a number of different reasons. They are a major source of energy, as well as containing essential amino-acids, such as lysine, tryptophan, methionine, leucine, isoleucine and valine, which are essential to human health, but which the body cannot synthesize. Proteins are also the major structural components of many natural foods, often determining their overall texture, e.g., tenderness of meat or fish products.Isolated proteins are often used in foods as ingredients because of their unique functional properties, (i.e., their ability to provide desirable appearance, texture or stability). Typically, proteins are used as gelling agents, emulsifiers, foaming agents and thickeners. Many food proteins are enzymes which can enhance the rate of certain biochemical reactions. These reactions can have either a favorable or detrimental effect on the overall properties of foods. Food analysts are interested in knowing the total concentration, type, molecular structure and functional properties of the proteins in foods (Skjaerven et al., 2009).

\section{MATERIALS AND METHODS}

\section{Experimental plants}

Marjoram plants were obtained from Genetic Engineering and Biotechnology Research Institute (GEBRI), University of Sadat city, Sadat city, Egypt

\section{Protein analysis}

Discontinuous polyacrylamide gel electrophoresis (SDS-PAGE) was used for Total solubleprotein analysis according to the method adopted by Stegmanetal. (1987) and Hemeida (1994).

\section{Sample preparation}

Half gram from each sample of control and each treatment leaves was grinded. The samples were extracted in $1 \mathrm{ml}$ of extraction buffer consisting of $0.15 \mathrm{M}$ Tris $\mathrm{HCl}, 2 \%$ Trition X100 and 1\% B-mercaptoethanol. The extracts were centrifuged at $15000 \mathrm{rpm}$ for 30 minutes and the supernatant was stored at $-20^{\circ} \mathrm{C}$ until used for electrophoresis.

For loading, $50 \mu \mathrm{l}$ of the extract was mixed with $25 \mu \mathrm{l}$ of SDS/mercaptoethanol (ME) solution (5\% each) and incubated at $100^{\circ} \mathrm{C}$ for three min. in boiling water bath. Sucrose (10\%) was added to the latter solution to increase the specific gravity of the supernatant. As a tracking dye, $0.01 \%$ Amido black $(2 \mu \mathrm{l}$ of $0.5 \%$ Amido Black solution to $100 \mu$ l of the supernatant) was added to the latter solution before use. Samples $(30 \mu$ l each) were then applied into the wells of the gel.

\section{Stock solutions}

Acrylamide monomer solution contained $30 \mathrm{gm}$ Acryl amide, and $0.8 \mathrm{gm}$ Bis- Acryl amide. Solution was brought up to $100 \mathrm{ml}$ with water. Solution was filtered and stored at $4^{\circ} \mathrm{C}$ in dark (30 days max) 
4.2. Separating gel buffer (1.5 M Tris$\mathrm{HCl} \mathrm{pH} \mathrm{8.8)} \mathrm{contained} 18.168 \mathrm{gm}$ Tris, and 20 $\mathrm{ml} 2 \mathrm{~N} \mathrm{HCL}$. Solution was brought up to $100 \mathrm{ml}$ with water. Solution was filtered and stored at $4^{\circ} \mathrm{C}$ in dark (30 days max)

4.3. Stacking gel buffer (1M Tris- $\mathrm{HCl}$, $\mathrm{pH}$ 6.8) contained $12.11 \mathrm{gm}$ Tris, and $17 \mathrm{ml} 2 \mathrm{~N}$ HCL. Solution was brought up to $100 \mathrm{ml}$ with water. Solution was filtered and stored at $40 \mathrm{c}$ in dark (30 days max)

4.4. SDS solution $10 \%(w / v)$ contained $10 \%$ SDS

4.5. Electrode buffer $(0.05 \mathrm{M}$ Tris, $0.384 \mathrm{M}$ glycine, $0.1 \% \mathrm{SDS} \mathrm{pH}$ 8.3) contained $28.8 \mathrm{gm}$ Glycine, $8 \mathrm{gm}$ Tris, and $1 \mathrm{gm}$ SDS. Solution was brought up to $1 \mathrm{~L}$ with water.

4.6. Commassie blue contained $1 \mathrm{gm}$ Commassie blue R-250, 0.25 gm Commassie blue G-250, $16 \mathrm{ml}$ Methanol, $40 \mathrm{ml}$ Acetic acid and $40 \mathrm{ml}$ water.

4.7. Staining solution contained $60 \mathrm{gm}$ TCA, $200 \mathrm{ml}$ Methanol, $20 \mathrm{ml}$ Acetic acid and $800 \mathrm{ml}$ water.

4.8. Distaining solution contained 240 $\mathrm{ml}$ Methanol, $40 \mathrm{ml}$ Acetic acid and $560 \mathrm{ml}$ water.

\section{Preparation of SDS polyacrylamide Gel}

Discontinuous polyacrylamide gel consisted of a resolving or separating (lower) gel and stacking (upper) gel was used. The stacking gel acts to concentrate large sample volumes resulting in better band resolution. Gel was prepared according to Laemmli(1970) 5.1 Separating gel $(10 \%)$ contained 0.75 Monomer solution, $5 \mathrm{ml}$ Separating buffer, 15 ml Water, $300 \mu \mathrm{l} 10 \%$ SDS, $30 \mu$ ITEMED and $75 \mu$ Ammonium persulfate.

5.2. Preparation of stacking $\mathrm{Gel}(4 \%)$ contained $1.33 \mathrm{ml}$ Monomer solution, $1.67 \mathrm{ml}$ Stackingbuffer, $7 \mathrm{ml}$ Water, $10.00 \mu \mathrm{l} 10 \%$ SDS, $10.00 \mu \mathrm{l}$ TEMED $\quad$ and $33.5 \mu \mathrm{l} \quad 10 \%$ Ammonium persulfate.

To prepare monomer solution of both separating and stacking gels, all reagents were combined, except TEMED and Ammonium persulfate which were added prior to casting the gels

\section{Running conditions}

Electrophoresis experiments (Shelton Scientific Mfg Gel electrophoresis apparatus) were conducted under cooling using a 150 volt electric current exerting its effect through the 6 hours running period.

\section{Staining procedure}

SDS polyacrylamide gels were kept overnight in the staining solution which was composed of $2.5 \mathrm{ml}$ of $1 \%$ aqueous solution of Commassie Blue R-250 added to $100 \mathrm{ml}$ TCA/Methanol/Acetic acid aqueous solution.

\section{Distaining procedure}

For distaining, the gels were immersed overnight in the distaining solution and then photographed and analyzed. 


\section{RESULTS}

\section{Protein analysis}

This experiment was planned and achieved in order to determine any probable variation in the banding pattern of total soluble proteins due to the exposure of marjoram to pathogen, biocontrol agent, pathogen and single biocontrol agent or pathogen and combination treatment of biocontrol agents. Tissue extracts from leaves was assayed by electrophoretic analyses and then estimated by electropherograms scan unit (Pexil) and using Scannogram Phoretix 1 D software (Ibrahim et al., 2014)

Total soluble proteins patterns of leaves extracted from different treatments and control are shown in Figure 1. For control, healthy plants, plants and pathogen and plants and bioagent were used separately. Broadway Dual Pre-stained Protein Marker (in tRON Biotechnology, Germany) was used as molecular

Proteins bands recorded by the scannogram analysis are illustrated in Figure (2).

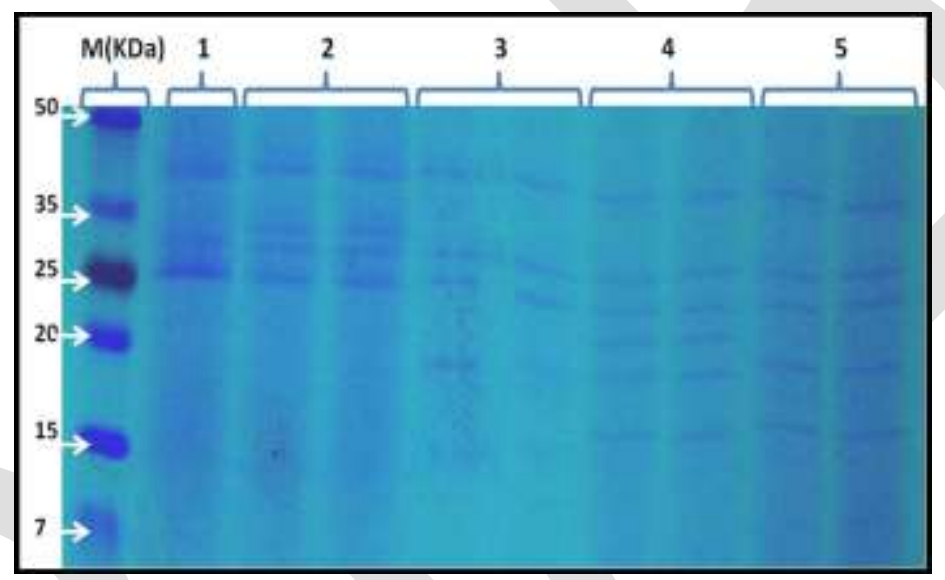

Figure1.SDS electrophoresis of total soluble protein patterns of controls, different treatments and molecular marker.M: molecular marker,1: Bacillus megaterium, 2: Fusarium aquaeductuum 3: Trichoderma harzinum + Fusarium aquaeductuum,4: Control 5: Bacillus megaterium +Trichoderma harzinum +Trichoderma hamatum +Fusarium aquaeductuum.

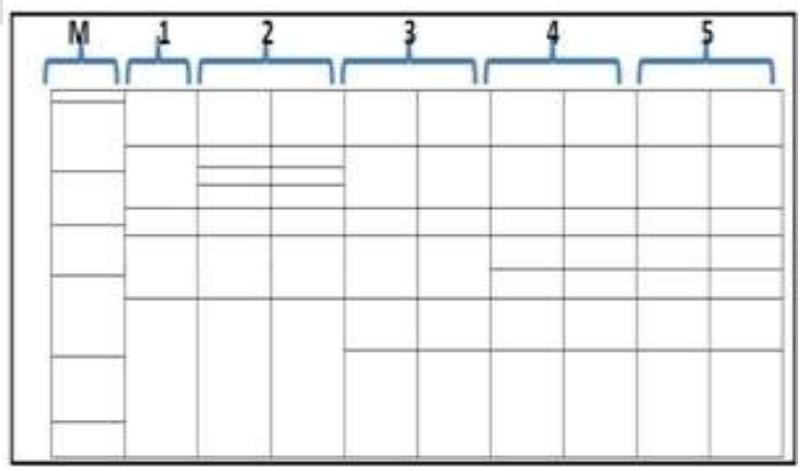

Figure 2.Dendogram of total soluble protein patterns electrophoresis of controls, different treatments and molecular marker.M: molecular marker,1: Bacillus megaterum, 2: Fusarium aquaeductuum, 3: Trichoderma harzinum, + Fusarium aquaeductuum, 4: Control, 5: Bacillus megaterum + Trichoderma harzinum + Trichoderma hamatum + Fusarium aquaeductuum

The Molecular weight of obtained bands and One/Zero data is presented in Table (1). 
Table 1.Molecular weights of bands and One/Zero data for controls and different treatments.

\begin{tabular}{|c|c|c|c|c|c|c|c|c|c|}
\hline MW & $\mathbf{1}$ & $\mathbf{2}$ & $\mathbf{3}$ & $\mathbf{4}$ & $\mathbf{5}$ & $\mathbf{6}$ & $\mathbf{7}$ & $\mathbf{8}$ & $\mathbf{9}$ \\
\hline $\mathbf{4 0 . 3 6 1}$ & 1 & 1 & 1 & 1 & 1 & 1 & 1 & 1 & 1 \\
\hline $\mathbf{3 5 . 8 8}$ & 0 & 1 & 1 & 0 & 0 & 0 & 0 & 0 & 0 \\
\hline $\mathbf{3 2 . 3 6 9}$ & 0 & 1 & 1 & 0 & 0 & 0 & 0 & 0 & 0 \\
\hline $\mathbf{2 8 . 2 9 6}$ & 1 & 1 & 1 & 1 & 1 & 1 & 1 & 1 & 1 \\
\hline $\mathbf{2 4 . 2 2 1}$ & 1 & 1 & 1 & 1 & 1 & 1 & 1 & 1 & 1 \\
\hline $\mathbf{1 9 . 9 6 3}$ & 0 & 0 & 0 & 0 & 0 & 1 & 1 & 1 & 1 \\
\hline $\mathbf{1 6 . 8 3 9}$ & 1 & 1 & 1 & 1 & 1 & 1 & 1 & 1 & 1 \\
\hline $\mathbf{1 2 . 5 4 7}$ & 0 & 0 & 0 & 1 & 1 & 1 & 1 & 1 & 1 \\
\hline
\end{tabular}

MW: molecular weight,1: Bacillus megaterum,2and 3: Fusarium aquaeductuum4 and 5: Trichoderma harzinum, + Fusarium aquaeductuum6 and 7: Control8 and 9: Bacillus megaterium + Trichoderma harzinum + Trichoderma hamatum + Fusarium aquaeductuum.

\section{DISCUSSION}

Obtained results reveal that there is a total of 8 bands observed in the gel. The number of bands was the same (5 bands) for healthy plants and controls, healthy plants and biocontrol agent and diseased plants and combination treatment of biocontrol agents but with different molecular weights for some bands. With diseased plants and diseased plants and single biocontrol agent there were 7 and 6 bands, respectively.

Furthermore, the present data show that the specific protein molecular weights rangedfrom 40.361 to $12.547 \mathrm{KD}$ (16). Bands number $2(35.88 \mathrm{KD})$ and 3 (32.369 KD) were commonly observed in diseased plants, while band number 6 of molecular weight 19.963KD was unique band detected in diseased plants and single biocontrol agent and in combination treatment of biocontrol agents. As observe in Figure (1) the density of band 6 in diseased plants and single biocontrol agent was more than that of diseased plants and combination treatment of biocontrol agents. There was a specific band (band number 8 with molecular weight of $12.547 \mathrm{KD}$ ) expressed in healthy plants and biocontrol agents, diseased plants and single biocontrol agent and diseased plants and combination treatment of biocontrol agents. 


\section{REFERENCES}

Abd E.M.A and El-Metwally, N. Y. (2010). "Effect of Marjoram Leaves on Injured Liver in Experimental Rats", Report and Opinion,2(12), 181-191.

Abdel-Massih, R.M; Fares, R.; S. Bazzi, S.; El-Chami N. and Baydoun E.(2010). "The Apoptotic and Anti-Proferative Activity of Origanum Majorana Extracts on Human Leukemic Cell Line". Leuk. Res., 34(8), 1052-1056.

Al-Howiriny, T.; Alsheikh, A; Algasoumi, S.; Al-Yahya, M.; El-Tahir, K. and Rafatullah S(2009). "Protective Effect of Origanum Majorana L. 'Marjoram' on Various Models of Gastric Mucosal Injury in Rats". Am. J. Chin. Med., 37(3): 531-545.

Amarowicz, R., Żegarska, Z., Rafałowski, R., Pegg, R.B., Magdalena Karamać, M. And Kosińska, A. (2009). "Antioxidant Activity and Free Radical-Scavenging Capacity of Ethanolic Extracts of Thyme, Oregano, and Marjoram". Eur. J. Lipid Sci. Technolog., 111, 1111-1117.

Dragland, S.; Senoo, H.; Wake, K.; Holte. K. and Blomhoff, R.(2003). "Several Culinary and Medicinal Herbs are Important Sources of DietaranTioxidants". J. Nutr., 133(5): 1286-1290.

El-Ghorab, A. H.; Mansour, A.F. and ElMassry, K.F. (2004), "Effect of extraction methods on the chemical composition and antioxidant activity of Egyptian marjoram (Majorana hortensis Moench)". Flavour and Fragrance Journal; 19(1):54-61.

Hemeida, A. A. (1994). "Cytological and Biochemical Genetic Studies in Fishes".
Ph. D. Thesis. Fac. Agric. Alexandria Univ., Egypt.

Ibrahim A. Ibrahim, Medhat H. Hashem, Alaa A. Hemeida, Mona M. Hassan and Ahmed I.A. Maksoud. (2014). "Characterization of genetic diversity of Date palm (Phoenix dactylifera L.) cultivars collected from New Valley governorate (El-Kharga and Dakhleh) based on morphological variability and molecular markers". Life Science Journal 11:879- 889

Novak, J.; Lukas, B. and Franz, C.M. (2008)."The Essential Oil Composition of Wild Growing Sweet Marjoram (Origanum majorana L., Lamiaceae) from Cyprus-Three Chemotypes". Journal of Essential Oil Research, 20(4), 339-341.

Ramadan, G.; El-Beih, N.M.; Arafa, N.M. and Zahra, M.M. (2013). "Preventive effects of Egyptian Sweet Marjoram (Origanum Majorana L.) Leaves on Haematological Changes and Cardiotoxicity in Isoproterenol-Treated Albino Rats". Cardiovascular Toxicology, 13(2), 100-9. Skjaerven, L.; Hollup, S.M. and Reuter, N. (2009). "Normal mode analysis for proteins".Journal of Molecular Structure, THEOCHEM, 898, 42-48.

Stegmann, T., H W Morselt, F P Booy, J F van Breemen, G Scherphof, J Wilschut. (1987). Functional reconstitution of influenza virus envelopes. EMBO J. 6(9): 2651-2659. 